\title{
Cutaneous Metastases of Urothelial Carcinoma: Mini Review
}

\author{
Lea Rath-Wolfson ${ }^{1,3}$ and Asaf Shvero ${ }^{* 2,3}$ \\ ${ }^{1}$ Department of Pathology, Hasharon hospital, Rabin Medical Center, Petah-Tikva, Israel \\ ${ }^{2}$ Department of Urology, "Sheba" Medical Center, Tel-Hashomer, Israel \\ ${ }^{3}$ Sackler School of Medicine, Tel-Aviv university, Tel Aviv, Israel
}

Submission: May 08, 2019; Published: May 16, 2019

"Correspondence Author: Asaf Shvero, Department of Urology, "Sheba" Medical Center, Tel-Hashomer, Sackler School of Medicine, Tel-Aviv university, Israel

Abstract

Introduction: Cutaneous metastasis of urinary bladder carcinoma is extremely rare with a limited number of published cases. An awareness of this rare clinical entity and high index of suspicion is needed for diagnosis, as it can occur months or rarely even years after the primary cancer.

Material and Methods: A retrospective review of the literature

Conclusion: Metastatic disease should always be considered in the differential diagnosis in patients with a previous history of bladder cancer who present with cutaneous nodules, even many years after the initial diagnosis at the primary site.

Keywords: Cutaneous metastases; Bladder; Urothelial Cancer

Abbreviations: UC-Urothelial Carcinoma; TCC-Transitional Cell Carcinoma; TRP: Transient Receptor Potential

\section{Introduction}

Bladder cancer is the most common genitourinary tract cancer, and the 9th most common cancer in the world with over 330,000 new cases/year, over 30,000 deaths/year and a 3.8:1 rate between men and women $[1,2]$. The most common bladder cancer is Urothelial Carcinoma (UC), also known as Transitional Cell Carcinoma (TCC). Other much common types are adenocarcinoma, leiomyosarcoma, sarcomatoid carcinoma etc. The progression of normal cells to a tumorigenic and metastatic state involves the accumulation of mutations in multiple key signalling proteins, encoded by oncogenes and tumor suppressor genes. Recently, members of the transient receptor potential (TRP) channel family have been included in the oncogenic and tumor suppressor protein family. TRPM1, TRPM8, and TRPV6 are tumor suppressors and oncogenes in localized melanoma and prostate cancer, respectively [3]. Changes in TRPV1 expression occur during the development of transitional cell carcinoma (TCC) of human bladder. A progressive decrease in TRPV1 expression as the TCC stage increases triggers the development of a more aggressive gene phenotype and invasiveness [4]. The most common sites for metastases from urothelial carcinoma are liver, lung and bone. Cutaneous metastases are very rare and only few cases have been published in the literature. $17 \%$ of all cutaneous metastases derive from urothelial carcinoma of the bladder [5].

\section{Clinical Manifestations}

In all the cases we revised in the literature, cutaneous metastases were preceded by bladder urothelial carcinoma. All patients presented with symptoms of cutaneous lesions. The age ranged between 50 and 80 years and all were males. Some presented with multiple reddish nodules on the neck and chest wall, resembling Herpes Zoster [6]. Others presented with swelling of a limb and well-demarcated macular-nodular rash on the thigh [7]. One presented with disseminated pigmented skin lesions [8], while another had multiple nodular swelling over the body with no lymphadenopathy and no other manifestations [9]. The time interval between the original tumor and the skin metastases ranged between 3 week and 8 years.

\section{Histopathology}

All skin lesions were biopsied and on the classical Hematoxylin \& Eosin stain a metastatic epithelial tumor was 
found. Immunohistochemical stains were performed in order to prove the origin of the tumor. The tumors showed strong positivity to cytokeratin 7, cytokeratin 20 and p-63. Tumor cells were negative for PSA and thyroid transcription factor 1 (TTF1). The above cytokeratin immunoprofile is consistent with metastatic urothelial carcinoma.

\section{Discussion}

The first reported case of cutaneous metastasis of urothelial carcinoma of the urinary bladder was in 1909 [10]. From the published literature cutaneous metastases occur most often within 18 months of the primary diagnosis, and only very few some years later [7]. Metastatic infiltration of the skin or subcutaneous tissue can occur due to the direct tumor invasion, hematogenous or lymphatic spread or as a result of iatrogenic implantation of the tumor cells [5]. It is notable that even superficial, non-invasive, urothelial carcinoma show dissemination in $20 \%$ of the cases. There may be cutaneous metastases even in absence of muscle invasive disease [11]. Cutaneous metastases are a poor prognostic factor with generally less than 1-year median survival [12].

\section{Conclusion}

Cutaneous metastases may mimic dermatological disorders. Clinicians and pathologists should be aware of this entity and consider performing a biopsy. Metastatic lesions often preserve histological similarities with the primary lesion, but they may as well be in a poorer differentiated state. In such cases the immunohistochemical stains can aid the diagnosis and exclude metastases from other sites.

\section{Conflict of Interest}

The authors declare there are none.

\section{References}

1. Babjuk M, Burger M, Zigeuner R, Shariat SF, van Rhijn BW, et al. (2013) EAU guidelines on non-muscle-invasive urothelial carcinoma of the bladder: update 2013. Eur Urol 64(4): 639-653.

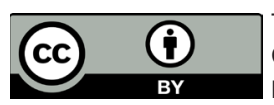

2. Ploeg M, Aben KK, Kiemeney LA (2009) The present and future burden of urinary bladder cancer in the world. World J Urol 27(3): 289-293.

3. Weiqun Yu, Warren GH, Apodaca G, Zeidel ML (2011) Expression and distribution of transient receptor potential (TRP) channels in bladder epithelium. Am J Physiol Renal Physiol 300(1): 49-59.

4. Santoni G, Caprodossi S, Farfariello V, Liberati S, Gismondi A, et al. (2012) Antioncogenic Effects of Transient Receptor Potential Vanilloid 1 in the Progression of Transitional Urothelial Cancer of Human Bladder. ISRN Urol 2012: 458238.

5. Mueller TJ, Wu H, Greenberg RE, Hudes G, Topham N, et al. (2004) Cutaneous metastases from genitourinary malignancies. Urology 63: 1021-1026.

6. Somani BK, Prita D, Grant S, Nabi G, N’Dow J (2006) Herpetiform cutaneous metastases from transitional cell carcinoma of the urinary bladder: immunohistochemical analysis. J Clin Pathol 59(12): 13311333.

7. Lees AN (2015) Cutaneous metastasis of transitional cell carcinoma of the urinary bladder eight years after the primary: a case report. J Med Case Rep 9: 102.

8. Kerkeni W, Ayari Y, Charfi L, Bouzouita A, Ayed H, et al. (2017) Transitional Bladder Cell Carcinoma Spreading to the Skin. Urol Case Rep 11: 17-18.

9. Narayana MA, Patnayak R, Rukmangadha N, Chowhan AK, Kottu R, et al. (2014) Cutaneous metastasis of transitional cell carcinoma of the urinary bladder: Cytological aspect. J Cytol 31(1): 50-52.

10. Azua D (1909) Informaciones dermo-sitilograficas: carcinosis secondaria cutanea. Rev Clin Madrid 6: 201-209.

11. Bernardes Filho F, de Melo AS, Pires AR, Lupi O, das Neves DG, et al. (2016) Cutaneous invasion from sarcomatoid urothelial carcinoma: clinical and dermatopathologic features. An Bras Dermatol 91(1): 73-79.

12. Block CA, Dahmoush L, Konety BR (2006) Cutaneous metastases from transitional cell carcinoma of the bladder. Urology 67(4): 846.e15-17.

\section{Your next submission with Juniper Publishers will reach you the below assets}

- Quality Editorial service

- Swift Peer Review

- Reprints availability

- E-prints Service

- Manuscript Podcast for convenient understanding

- Global attainment for your research

- Manuscript accessibility in different formats

( Pdf, E-pub, Full Text, Audio)

- Unceasing customer service

Track the below URL for one-step submission https://juniperpublishers.com/online-submission.php 